\title{
添加されたメチルイソチオシアネートのワイン中での化学変化
}

(平成 5 年 5 月 26 日受理)

\author{
安井陽子*1 松下 純雄*
}

\section{Chemical Change of Methyl Isothiocyanate Added to Wine}

\author{
Yoko Yasui and Sumio Matsushita
}

(The Hyogo Prefectural Institute of Public Health: 2-1-29, Arata-cho, Hyogo-ku, Kobe 652, Japan)

\begin{abstract}
Methyl isothiocyanate (MITC) added to wine was found to react with ethanol to produce methyl thiourethane. MITC and methyl thiourethane were extracted with ethyl acetate and the extract was analyzed by gas chromatography with a flame photometric detector (S-mode).

MITC in wine imported from Italy was detected in the range of 0.06 to $0.09 \mathrm{ppm}$ and methyl thiourethane was detected at 0.10 to $0.17 \mathrm{ppm}$ in three brands.
\end{abstract}

(Received May 26, 1993)

Key words：メチルイソチオシアネート methyl isothiocyanate; メチルチオウレタン methyl thiourethane; ワイン wine; ガスクロマトグラフィー (FPD) gas chromatography (FPD); 高 速液体クロマトグラフィー high performance liquid chromatography (HPLC)

緒言

イタリア産ワインの一部に, 土壤くん蒸剤のメチルイ ソチオシアネート (methyl isothiocyanate: 以下 MITC と略）が発酵調整剂として添加されていることが 1992 年アメリカ食品医薬品局 (FDA) の調查で判明し た.

我が国であ厚生省の指示により ${ }^{1)}$, 都道府県の研究所 などで輸入ワイン（1,857 検体）中の MITC の分析が行 われた. ところが MITC が検出されたワイン（20 検体） が検查実数 ${ }^{2}$ の約 $1 \%$ と非常に少なかったことと, MITC の反応性を考慮し, 貯蔵中にワイン中の MITC が 化学変化を起こし, 他の化合物に変化したのではないか と考え, 反応生成物について検討を行った結果を報告す る. 更に市販のイタリア産ワイン中の MITC 及び反応生 成物の測定結果も併せて報告する。

\section{実験方法}

1. 試料

イタリア産ワイン 34 検体を用いた.

2. 試 薬 等

1) MITC：和光純薬工業(株)製 1 級品.

購入した 1 級品を減圧下で蒸留し，沸点 $118 \sim 119^{\circ}$

\footnotetext{
* 兵庫県立衛生研究所： $=652$ 神戸市兵庫区荒田町 2-1-29
}

の白色の留分（直ちに白色の結晶となる）を分取したも のを使用した.

2) メチルチオウレタン: MITCをエタノール (99.5\%) に溶解し，還流冷却器を取り付け，沸騰水浴中 で, 8 時間加温する. 冷後, 減圧下 $35 \mathrm{~mm}$ で蒸留し, 沸 点 $102 \sim 103^{\circ}$ の留分を分取したものを使用した.

3) 酢酸エチル，アセトニトリル， $n$-ヘキサン及びェ タノール：和光純薬工業(株)製，高速液体クロマトグラ ᄀ用

4) その他の試薬：和光純薬工業(株)製, 試薬特級及 びガスクロマトグラフ用

5）薄層クロマトグラフィー (TLC) 用プレート：メル $ク$ 社製 Pre-Coated Silica gel 60 with fluorescent indicator (F 254)

購入品をあらかじめ酢酸エチルで展開し乾燥させたも のを使用した。

3. 装置

1）高速液体クロマトグラフ：(株)島津製作所製 LD$6 \mathrm{AD}$ シリーズ

2) 炎光光度検出器付ガスクロマトグラフ (FPD-GC) (S-mode)：(株)柳本製作所製 YANACO G 2800

3）ガスクロマトグラフーマススペクトロメーター (GC/MS): Hewlett Packard 5890, 5970 Series Mass 
Selective Detector 付

\section{4. 分析操作}

\section{1 標準溶液の調製}

1) MITC100 mg をアセトニトリル及び酢酸エチル に溶解し $100 \mathrm{ml}$ としたものを標準原液とした $(1 \mathrm{mg} /$ $\mathrm{ml})$. 標準原液をアセトニトリル及び酢酸エチルで適宜 希釈して標準溶液を調製した。

2)メチルチオウレタン $100 \mathrm{mg}$ をひょう取し， MITC 標準溶液と同様に操作して標準溶液を調製した。

\section{2 試験溶液の調製}

試料 (ワイン) $50 \mathrm{ml}$ に食塩 $18 \mathrm{~g}$ を加え, 酢酸エチル $10 \mathrm{ml}$ で振とう抽出した後，数分間放置するかあるいは 遠心分離 $(3,000 \mathrm{rpm}, 2$ 分) し, 酢酸エチル層を分取す る. 酥酸エチル層を硫酸ナトリウム（無水）で脱水し， FPD-GC 用試験溶液とした.

\section{3 クロマトグラフィー条件}

HPLC 及び FPD-GC (S-mode) の測定条件はそれぞれ Table 1 及び Table 2 に示した.

Table 1. HPLC Conditions for Determination of MITC and Methyl Thiourethane

\begin{tabular}{ll}
\hline Column & $:$ Wakogel $5 \mathrm{C} 18,4.6 \times 250 \mathrm{~mm}$ \\
Mobile phase & $:$ Acetonitrile-water $(6: 4)$ \\
Flow rate & $: 1 \mathrm{ml} / \mathrm{min}$ \\
Detector & $: \mathrm{UV} 244 \mathrm{~nm}$ \\
Sample size & $: 10 \mu 1$ \\
\hline
\end{tabular}

Table 2. FPD-GC Conditions for Determination of MITC and Methyl Thiourethane in Wine

\begin{tabular}{l}
\hline \hline Column $: 25 \%$ PEG-20 M 60 80 mesh $2 \mathrm{~m}$ \\
Column temp. $: 140^{\circ} \mathrm{C}(7 \mathrm{~min})-$ Flush-210 \\
Detector temp. $: 250^{\circ} \mathrm{C}$ \\
Injection temp.: $250^{\circ} \mathrm{C}$ \\
Sample size $\quad: 5 \mu 1$ \\
\hline
\end{tabular}

\section{結果及び考察}

\section{MITC とエタノールの反応}

MITC をワインとほぼ同様のアルコール濃度 $(10 \%)$ のエタノールに $10 \mu \mathrm{g} / \mathrm{ml}$ になるように添加し，還流冷 却器を付けて水浴中で加温した後, 高速液体クロマトグ ラフを用いて変化を追跡した。 また同様に MITC 添加エ タノール溶液を室温及び $5^{\circ}$ で保存し，その変化を追跡 した結果, Fig. 1 に示したように MITC (Rt $5.3 \mathrm{~min})$ の ピークは時間の経過ととあに減少し, 逆に Rt $4.6 \mathrm{~min} の$ ピークが増大することが判明した。

\section{TLCによる反応生成物の分離}

蛍光指示薬添加シリカゲル薄層プレートに, MITC と エタノールを反応させた液を塗布し, 酶酸エチルで展開

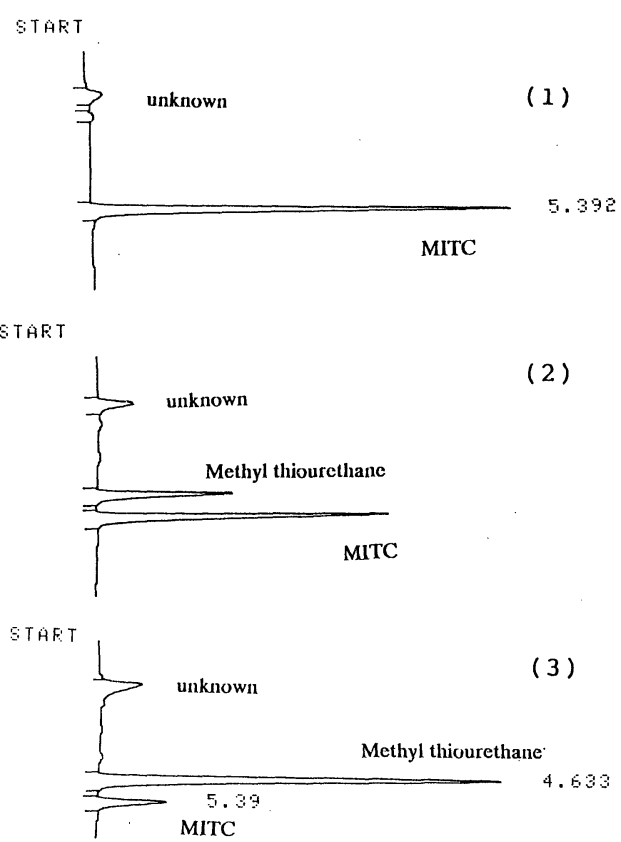

Fig. 1. The decrease of MITC and the increase of methyl thiourethane in $10 \%$ ethanol solution by high performance liquid chromatography

Chromatographic conditions: see Table 1; (1): initial (MITC, $10.2 \mu \mathrm{g} / \mathrm{ml}$ ); (2): after 15 days (MITC, $7.0 \mu \mathrm{g} / \mathrm{ml}$, methyl thiourethane $0.3 \mu \mathrm{g} / \mathrm{ml}$ ); (3): after 75 days (MITC 1.7 $\mu \mathrm{g} / \mathrm{ml}$, methyl thiourethane $0.9 \mu \mathrm{g} / \mathrm{ml}$ ) at room temperature

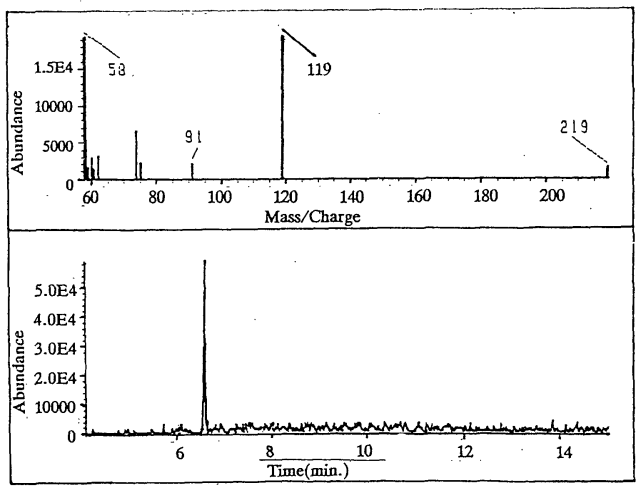

Fig. 2. Mass spectrum and chromatogram of methyl thiourethane

したところ, $R f$ 值 0.8 に反応生成物の黒色のスポット が検出された。

そこで蛍光指示薬無添加のシリカゲル薄層プレートを 用いて, 上記 $R f 0.8$ 相当のスポット部分を集め, アセト 
ニトリルで溶出させたものを HPLC で測定したところ, $\mathrm{R} t 4.6$ 分にピークが検出された.

\section{GC/MS による反応生成物の同定}

シリカゲル薄層プレート Rf 0.8 相当のスポット部分 を, $n$-ヘキサンで溶出させ, へキサン層を GC/MS (測定 用カラムは DB-17 $0.25 \mathrm{mmA} \times 30 \mathrm{~m}$ を使用）により解 析したところ, Fig. 2 に示したように反応生成物はメチ ルチオウレタンであることが判明した，MITC とエタノ ールとの反応式は Fig. 3 に示した.

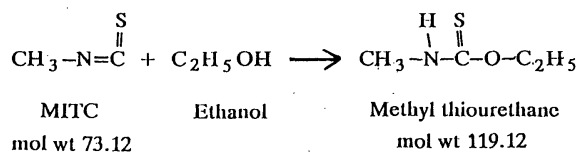

Fig. 3. Reaction mechanism of MITC and ethanol

\section{4. 定量法の検討}

MITC の分析法について, 我が国の農薬登録保留基準 記載のディーンスターク型蒸留装置を用いる方法 ${ }^{3}$ や, 有機溶媒で抽出後窒素ガスを噴霧し濃縮する方法を検討 した結果, 濃縮の過程で MITC が気散して, MITC の回 収率が非常に悪いことが判明した。またメチルチオウレ

Table 3. Recoveries of MITC Added to Wine by FPD-GC

\begin{tabular}{ccc}
\hline $\begin{array}{c}\text { Added } \\
(\mu \mathrm{g} / \mathrm{ml})\end{array}$ & $\begin{array}{c}\text { Recovery } \\
(\%)\end{array}$ & $\begin{array}{c}\text { Average } \pm \text { S.D. } \\
(\%)\end{array}$ \\
\hline 0.1 & 80.2 & $73.8 \pm 4.6$ \\
0.1 & 71.1 & \\
0.1 & 70.0 & \\
\hline 0.5 & 100.2 & $104.9 \pm 3.4$ \\
0.5 & 107.9 & \\
0.5 & 106.6 & \\
\hline
\end{tabular}

タンの場合にも, 濃縮方法に加え抽出溶媒の種類によっ て抽出率が大きく影響を受けることが分かった。そこで ワイン中の MITC 及びメチルチオウレタンを酢酸エチ ルで抽出し, 硫酸ナトリウム（無水）で脱水後, 濃縮せ ずに直接 FPD-GC (S-mode) で測定することとした。 ま たメチルチオウレタンの測定温度は $210^{\circ}$ (検出時間は 約 7 分）と高いことと, MITC の含有が認められた場合 には, 同時にメチルチオウレタンの検出があったことを 記録するために，同時測定を考慮して昇温で測定するこ ととした. この測定条件での MITC の検出限界は 0.2 ng, メチルチオウレタンの検出限界は $0.5 \mathrm{ng}$ であった.

\section{5. 添加回収実験の結果}

ワインに MITC 及びメチルチオウレタンを 0.1 及び $0.5 \mu \mathrm{g} / \mathrm{ml}$ になるように添加し，回収実験を行った結果 は Table 3, 4 に示したが, 非常に良い結果が得られた。

\section{6. メチルチオウレタンの生成量}

ワイン及び $10 \%$ エタノール溶液に MITC が $10 \mu \mathrm{g} /$ $\mathrm{ml}$ になるように添加し, 室温及び $5^{\circ}$ で 40 日間保存し た場合，メチルチオウレタンが生成されることが判明し た.

Table 5 に示したように, 各溶液中に測定されたメチ ルチオウレタン量は反応に使用され，消失した MITC 量

Table 4. Recoveries of Methyl Thiourethane Added to Wine by FPD-GC

\begin{tabular}{ccc}
\hline \hline $\begin{array}{c}\text { Added } \\
(\mu \mathrm{g} / \mathrm{ml})\end{array}$ & $\begin{array}{c}\text { Recovery } \\
(\%)\end{array}$ & $\begin{array}{c}\text { Average } \pm \text { S.D. } \\
(\%)\end{array}$ \\
\hline 0.1 & 93.9 & $100.6 \pm 4.7$ \\
0.1 & 103.8 & \\
0.1 & 104.2 & \\
\hline 0.5 & 99.2 & $98.2 \pm 0.7$ \\
0.5 & 97.6 & \\
0.5 & 97.8 & \\
\hline
\end{tabular}

Table 5. Residual MITC and Methyl Thiourethane Produced after 40 Days Standing

\begin{tabular}{|c|c|c|c|c|}
\hline \multirow{2}{*}{ Solution } & \multirow{2}{*}{$\begin{array}{l}\text { Residual MITC } \\
(\mu \mathrm{g} / \mathrm{ml})\end{array}$} & \multicolumn{2}{|c|}{ Methyl thiourethane $(\mu \mathrm{g} / \mathrm{ml})$} & \multirow{2}{*}{$\begin{array}{c}(\mathrm{A}) /(\mathrm{B}) \times 100 \\
(\%)\end{array}$} \\
\hline & & Detected (A) & Theoretical (B) & \\
\hline \multicolumn{5}{|l|}{ In $10 \%$ ethanol $^{1)}$} \\
\hline $5^{\circ} \mathrm{C}$ & 7.90 & 0.20 & 3.42 & 5.8 \\
\hline Room temp. & 4.54 & 0.54 & 8.89 & 6.0 \\
\hline \multicolumn{5}{|l|}{ In wine ${ }^{2)}$} \\
\hline $5^{\circ} \mathrm{C}$ & 7.10 & 0.18 & 4.72 & 3.8 \\
\hline Room temp. & 3.80 & 0.96 & 10.10 & 9.5 \\
\hline
\end{tabular}

\footnotetext{
1) Each value was measured by HPLC.
}

2) Each value was measured by FPD-GC.

MITC was added to $10 \mu \mathrm{g}$ per $\mathrm{ml}$ in each solution. 


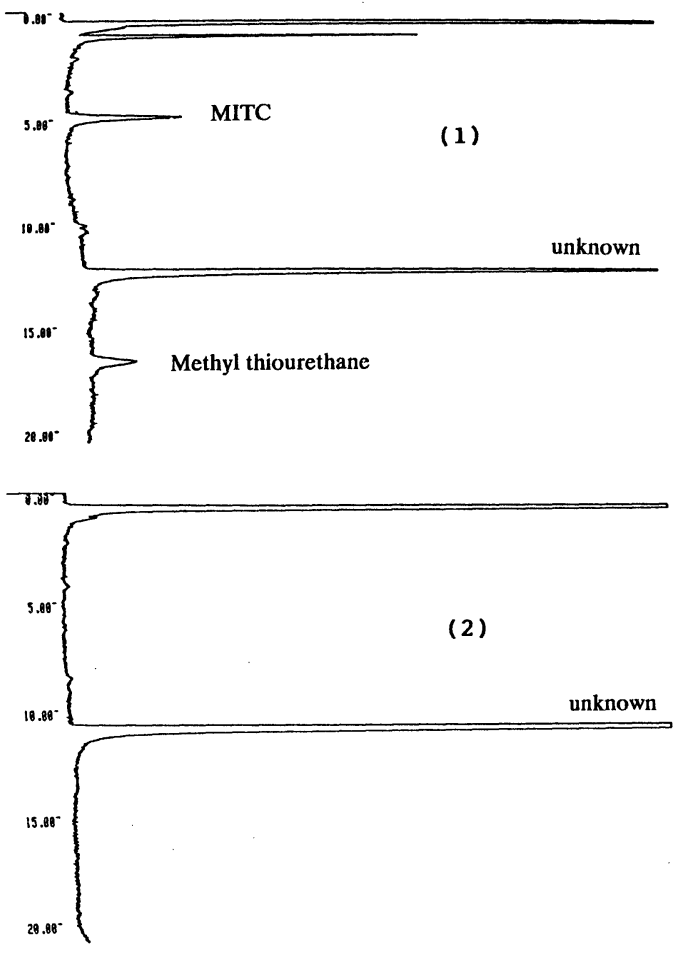

Fig. 4. Gas chromatograms of Italian wine that MITC and methyl thiourethane were detected (1) and no MITC was detected (2)

Chromatographic conditions: see Table 2

Table 6. Contents of MITC and Methyl Thiourethane in Italian Wine

\begin{tabular}{cccc}
\hline $\begin{array}{c}\text { Sample } \\
\text { number }\end{array}$ & Kind & $\begin{array}{c}\text { MITC } \\
(\mu \mathrm{g} / \mathrm{ml})\end{array}$ & $\begin{array}{c}\text { Methyl } \\
\text { thiourethane } \\
(\mu \mathrm{g} / \mathrm{ml})\end{array}$ \\
\hline 1 & White & 0.07 & 0.17 \\
2 & Red & 0.09 & 0.17 \\
3 & Red & 0.06 & 0.10 \\
\hline
\end{tabular}

Determination limits of MITC and methyl thiourethane were $0.2 \mathrm{ng}$ and $0.5 \mathrm{ng}$, respectively.

から計算される理論值の数パーセントにすぎなかった. つまりワインの場合は，メチルチオウレタンの測定量は 室温保存の場合は理論値の $9.5 \%$ （理論生成量 10.10 $\mu \mathrm{g} / \mathrm{ml}$, 測定量 $0.96 \mu \mathrm{g} / \mathrm{ml}$ ), $5^{\circ}$ 保存の場合には $3.8 \%$ （理論生成量 $4.72 \mu \mathrm{g} / \mathrm{ml}$, 測定量 $0.18 \mu \mathrm{g} / \mathrm{ml}$ ） であっ た.

\section{7. 輸入イタリア産ワイン中の MITC 及びメチルチオ ウレタンの定量}

Fig. 4 に MITC が検出された輸入イタリア産ワイン （白ワイン）のクロマトグラム (1)を示したが, MITCが 検出されたワイン 3 検体では, すべてメチルチオウレタ ンが検出された。測定結果は Table 6 に示したが， 3 検 体中のそれぞれの值は MITC $0.06 \sim 0.09 \mu \mathrm{g} / \mathrm{ml}$, 及び メチルチオウレタン $0.10 \sim 0.17 \mu \mathrm{g} / \mathrm{ml}$ であった. しか し MITC を検出しなかったワイン 31 検体ではメチルチ オウレタンは検出されなかった。

\section{まとめ}

1. ワインに添加された MITC の一部はワイン中で エタノールと反応し，メチルチオウレタンを生成するこ とが判明した。

2. ワイン中の MITC 及びメチルチオウレタンは酢 酸エチルで抽出し，硫酸ナトリゥム（無水）で脱水後 FPD-GC (S-mode) で測定することができた。 またそれ ぞれを $0.1 \mu \mathrm{g} / \mathrm{ml}$ 添加した場合の添加回収率は MITC $73.8 \%$, メルチオウレタン $100.6 \%, 0.5 \mu \mathrm{g} / \mathrm{ml}$ 添加の 場合は MITC 104.9\%，メチルチオウレタン $98.2 \%$ であ った.

3. MITC が検出された 3 検体のイタリア産ワイン中 の MITC 及びメチルチオウレタン量は $0.07 \mu \mathrm{g} / \mathrm{ml}$, $0.17 \mu \mathrm{g} / \mathrm{ml}$ (白ワイン), $0.09 \mu \mathrm{g} / \mathrm{ml}, 0.17 \mu \mathrm{g} / \mathrm{ml}$ (赤ワ イン）及び $0.06 \mu \mathrm{g} / \mathrm{ml}, 0.10 \mu \mathrm{g} / \mathrm{ml}$ (赤ワイン) であっ た.

4. 生成されたメチルチオウレタン量が，MITC の減 少量から推定される理論値の数パーセントと非常に少な かったこと，及び反応液のクロマトグラム中にその他の ピークが測定されたことから，メチルチオウレタン以外 の化合物が生成されている可能性む大であり, 他の生成 物について現在検索中である.

文献

1) 生活衛生局食品保健課疫業務管理室長通知：“イタリア産 ワインの取り扱いについで平成 4 年 4 月 16 日, 衛検第 115 号 (1992).

2）厚生省生活衛生局食品保健課事務連絡：“イタリア産ワイ ンのメチルイソチオシアネート (MITC) 検査結果 (都道府 県市区分）についで平成 4 年 6 月 25 日 (1992).

3）農薬環境保全対策研究会編：“農薬登録保留基準ハンドブ ック” p. 454〜456 (1990), 化学工業日報社. 